*ak RMIS View/Frint Document Cover Sheet tow

This document was retrieved from the Documentation and Records Manaqement (DRM) ISEARCH System. It is intended for Information only and may not be the most recent or updated version. Contact a Document Service Center (see Hanford Info for locations) if you need additional retrieval information.

Accession \#: D196012441

Document \#: SD-TD-FRD-003

Title/Desc:

FUNCTIONS \& REQUIREMENTS FOR THE LDUA INTEGRATED SYS

Pages: 32 


\begin{tabular}{l} 
2. To: (Receiving organization) \\
Remote System and Sensor \\
Appl ications ( $8 \mathrm{~A} 800)$ \\
\hline
\end{tabular}

5. Proj./Pros./Dept./Div.: Light Duty Utility Arm

8. Originator Remarks:

Approval and Release
3. From: (originating Orgenization)

Remote System and Sensor Applications (8A800)

\section{Coo. Engr.:}

G. R. Kiebel
4. Reloted EDT Mo.:

$$
\text { N/A }
$$

7. Purchase Order No.:

$\mathrm{N} / \mathrm{A}$

9. Equip./Component Mo.:

N/A

10. System/sldg./Facility:

11. Receiver Renarks:

$$
N / A
$$

12. Major Asen. Dug. No.:

$$
\text { N/A }
$$

13. Permit/Permit Application Mo.:

$$
\text { N/A }
$$

14. Required Response Date:

$$
\text { N/A }
$$

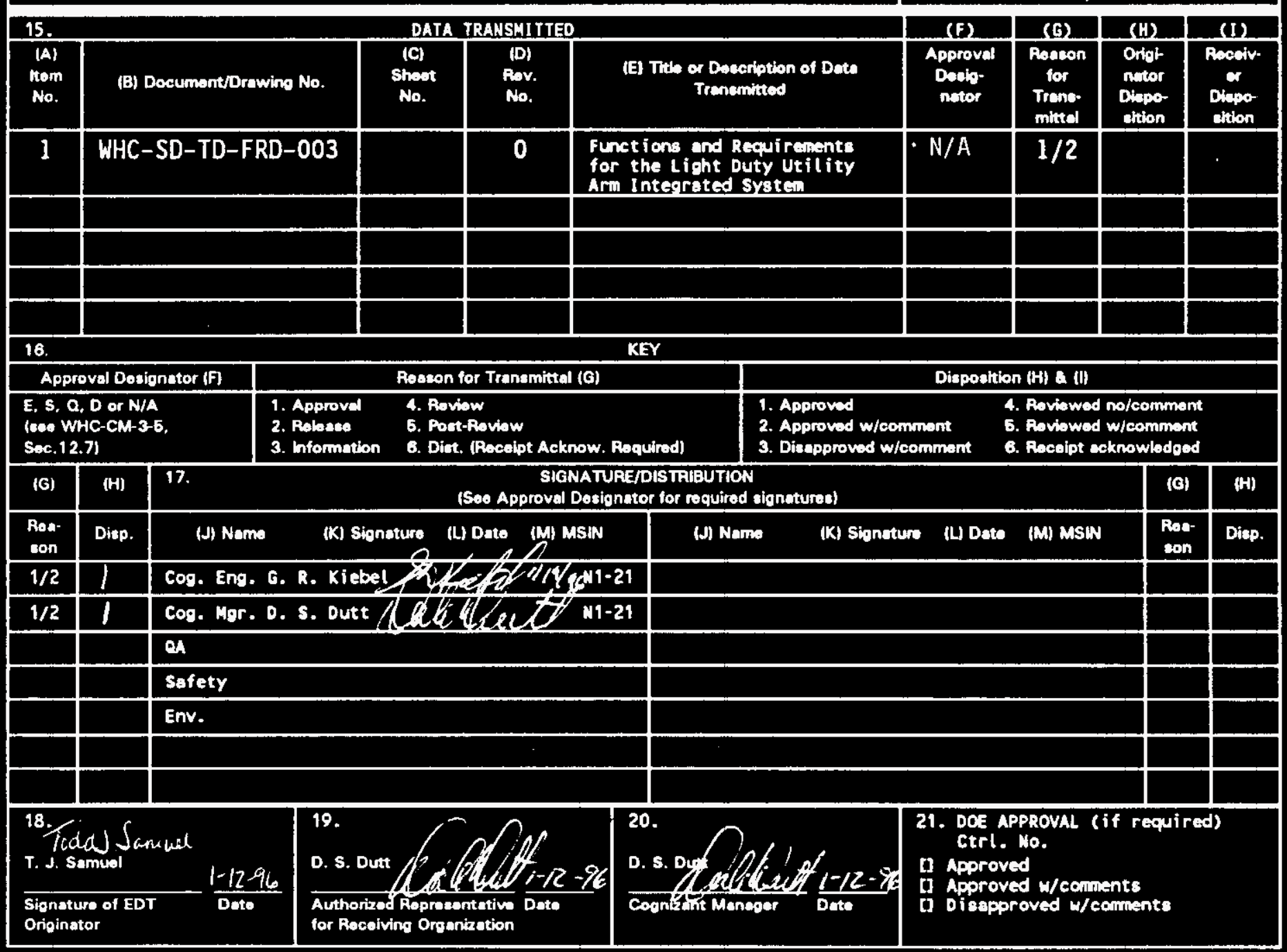




\title{
Functions and Requirements for the Light Duty Utility Arm Integrated System
}

\author{
G. R. Kiebel
}

Westinghouse Hanford Company, Richland, WA 99352

U.S. Department of Energy Contract DE-AC06-87RL10930

\begin{tabular}{|c|c|c|}
\hline $\begin{array}{l}\text { EDT/ECN: } \\
\text { Org Code: } \\
\text { B\&R Code: }\end{array}$ & $\begin{array}{l}612353 \\
8 A 800 \\
E W 4010000\end{array}$ & $\begin{array}{l}\text { UC: } 2060 \\
\text { Charge Code: } \\
\text { Total Pages: }\end{array}$ \\
\hline
\end{tabular}

Key Words: Functions and Requirements, Light Duty Utility Arm, LDUA, Integrated System

Abstract: The Light Duty Utility Arm (LDUA) Integrated System is a mobile robotic system designed to remotely deploy and operate a variety of tools in uninhabitable underground radiological and hazardous waste storage tanks. The system primarily provides a means to inspect, survey, monitor, map and/or obtain specific waste and waste tank data in support of the Tank Waste Remediation System (TWRS) mission at Hanford and remediation programs at other U.S. Department of Energy (DOE) sites.

TRADEMARK DISCLAIMER. Reference herein to eny specific commercial product, process, or service by trade neme, tredenark, manufacturer, or otheruise, does not necessarily constitute or imply its endorsement, recoumendation, or favor ind by the lnited states coverniont or any agency thereof or its contractors or subcontractors.

Printed in the United states of America. To dotain copies of this document, contact: WHC/Bcs Document Control Services, P.0. Box 1970, Mailstop H6-08, Richland ut 99352, Phone (509) 372-2420; Fax (509) 376-4989.
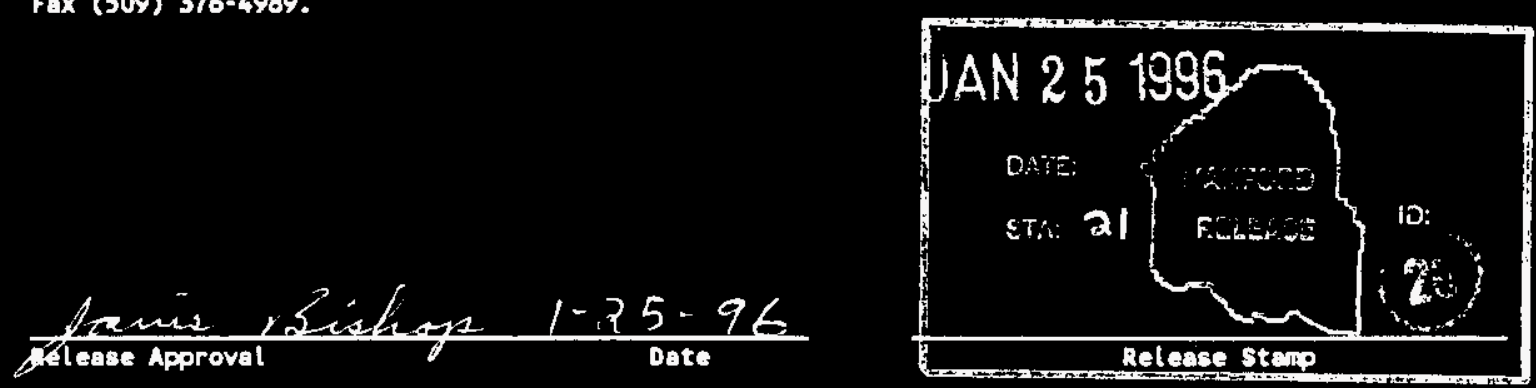

Approved for Public Release 


\section{CONTENTS}

\section{FUNCTIONS AND REQUIREMENTS FOR THE LIGHT-DUTY UTILITY ARH} INTEGRATED SYSTEM

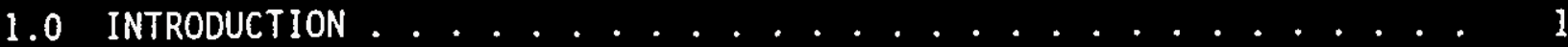

1.1 DESCRIPTION . . . . . . . . . . . . . . . 1

1.2 PURPOSE ........................ 1

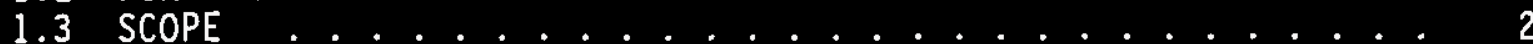

2.0 FUNCTIONS, REQUIREMENTS, AND ASSUMPTIONS . . . . . . . . . . . 3

2.1 LDUA INTEGRATED SYSTEM $(1000)$

2.1.1 LDUA Integrated System Function (1000) .. . . . . . . 3

2.1.2 LDUA Integrated System Requirements (1000) . . . . . . 3

2.1.3 LDUA Integrated System Assumptions (1000) . . . . . . 6

2.2 ARM/DEPLOYMENT SYSTEM (2000) ............... 7

2.2.1 Arm/Deployment System Function (2000) . . . . . . . . . 7

2.2.2 Arm/Deployment System Requirements (2000) . . . . . . . 7

2.2.3 Arm/Deployment System Assumptions (2000) . . . . . . . 9

2.3 TRIC SYSTEM (3000) . . . . . . . . . . . . . . . . . . 9

2.3.1 TRIC System Function (3000) . . . . . . . . . . . . 9

2.3.2 TRIC System Requirements (3000) . . . . . . . . . . . 9 9

2.3.3 TRIC System Assumptions (3000) . . . . . . . . . . . 11

2.4 OPERATIONS CONTROL CENTER (4000) . . . . . . . . . . . . . . . 12

2.4.1 Operations Control Center Function (4000) ....... 12

2.4.2 Operations Control Center Requirements (4000) . . . . . 12

2.4.3 Operations Control Center Assumptions (4000) . . . . . 14

2.5 END EFFECTOR $(6000)$. . . . . . . . . . . . . . . 15

2.5.1 End Effector Functions (6000) ........... 15

2.5.2 End Effector Systems Requirements (6000) ....... 15

2.5.3 End Effector Assumptions (6000) . . . . . . . . . 19

2.6 COLD TEST FACILITY (7000) . . . . . . . . . . . . . . . . . . 20

2.6.1 Cold Test Facility Functions (7000) . . . . . . . . . 20

2.6.2 Cold Test Facility Requirements (7000) . . . . . . . 20

2.6.3 Cold Test Facility Assumptions (7000) . . . . . . . 20

3.0 ENVIRONMENTAL CONDITIONS . . . . . . . . . . . . . . . 21

3.1 OUT-OF TANK ENVIRONMENT . . . . . . . . . . . . . . . 21

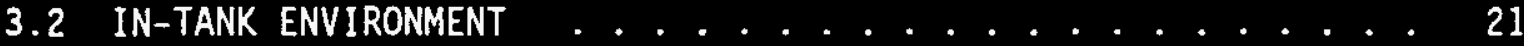

4.0 REFERENCES .......................... 23

5.0 REQUIREMENTS DOCUMENTS . . . . . . . . . . . . . . . 24

6.0 BIBLIOGRAPHY . . . . . . . . . . . . . . . . . . 27

GLOSSARY ........................ GL 
WHC-SD-TD-FRD-003, Rev. 0

FUNCTIONS AND REQUIREMENTS FOR THE LIGHT-DUTY UTILITY ARM INTEGRATED SYSTEM

\subsection{INTRODUCTION}

The Light-Duty Utility Arm (LDUA) Integrated System is a mobile robotic system designed to remotely deploy and operate a variety of tools in uninhabitable underground radiological and hazardous waste storage tanks. The system primarily provides a means to inspect, survey, monitor, map and/or obtain specific waste and waste tank data in support of the Tank Waste Remediation System (TWRS) mission at Hanford and remediation programs at other U.S. Department of Energy (DOE) sites. The TWRS mission is to "store, treat and immobilize the highly radioactive Hanford site waste in an environmentally sound, safe and cost-effective manner." The LDUA Integrated System is being developed for use primarily inside of single-shell tanks (SSTs) at the Hanford Site in Richland, Washington before and during the waste retrieval process. A major objective of the Underground Storage Tank - Integrated Demonstration (UST-ID) program is to demonstrate waste retrieval technologies in preparation for disposal. Waste retrieval is directly dependent on knowledge of waste chemical and physical properties and on operating experience in the tank environment. Because the in-tank environment precludes human entry, a remote system is required to deploy data gathering and remote rețieval devices. The need has been identified for a light-duty, in-tank positioning system for near-term deployment in tanks at the Hanford Site and at other sites to support mission needs and to gain operating experience. Immediate applications for the LDUA Integrated System include inspection systems for mapping waste and interior tank surfaces and deployment of end effectors (EEs) for determining tank integrity and waste speciation and rheology. Further applications during waste retrieval may include positioning of equipment performing in-tank maintenance and upset-condition recovery.

\subsection{DESCRIPTION}

Section 2.0 of this document contains the functions, requirements, and assumptions (F\&R) for each system and subsystem making up the LDUA Integrated System. The LDUA systems and subsystems are identified by their system number found in parenthesis. Safety, quality assurance, operations, and regulatory requirements are also included.

Section 3.0 describes the environments, both in-tank and out-of-tank, the LDUA Integrated System will experience during normal operation and must be designed to tolerate.

\subsection{PURPOSE}

The purpose of this document is to provide the basis for LDUA Integrated System engineering and design. The bases for the parameters specified herein have been derived from several sources including the objectives to demonstrate Environmental Restoration/Waste Management - Office of Technology Development 
(EM-50) technology. Although not specifically referenced, the bibliography identifies sources containing information significant in the development of this F\&R document.

\subsection{SCOPE}

The scope of this document includes the overall LDUA Integrated System requirements and subsystem general parameters. It also provides the general guidelines for subsystem interfaces. As detailed interface requirements develop, they shall be specified in an interface controls document. 


\subsection{FUNCTIONS, REQUIREMENTS, AND ASSUMPTIONS}

\subsection{LDUA INTEGRATED SYSTEM (1000)}

\subsubsection{LOUA Integrated System Function (1000)}

The LDUA Integrated System's function is to perform in-situ surveillance, inspection, and Data Acquisition on waste and waste tanks while applying "as low as reasonably achievable" (ALARA) concepts to reduce personnel and environmental hazards. Data gathered by the LDUA Integrated System will be used to assess tank structural integrity and determine the chemical and physical properties of tank waste.

\subsubsection{LDUA Integrated System Requirements (1000)}

The following requirements apply to all LDUA systems and subsystems unless specifically noted.

2.1.2.1 LDUA Integrated System General Requirements (1000). Generical1y, the LDUA Integrated System shall provide a mobile, remotely operated, multiaxis positioning system that will access the SSTs through existing riser penetrations. The LDUA Integrated System design shall be flexible and adaptive. The design shall provide a robotic platform capable of deploying in-situ tank surveillance, inspection, and Data Acquisition tools at multiple elevations and positions within the tank.

Additionally the LDUA Integrated System shall be designed and fabricated

1. to meet specifications 1 isted in Section 5.0, "Requirements Documents" for deployment into the SSTs at the Hanford Site

2. to interface with an SST's riser, tilted a maximum of \pm 5 degrees from vertica]

3. to interface with an SST's riser where the surrounding ground is a maximum of \pm 10 degrees from level

4. to allow for decontamination to levels acceptable for on-site transfers. For on-site transfers, equipment shall not package above $1000 \mathrm{dpm} / 100 \mathrm{~cm}^{2}$ beta/gamma and $20 \mathrm{dpm} / 100 \mathrm{~cm}^{2}$ a]pha
a. have removable contamination levels on the external of the
b. have an overall dose rate in excess of $200 \mathrm{mrem} / \mathrm{h}$ at contact and $10 \mathrm{mrem} / \mathrm{h}$ at $2 \mathrm{~m}$
c. have a dose rate where employees sit (e.g., vehicle cab area) exceeding $0.5 \mathrm{mrem} / \mathrm{h}$.

5. to provide confinement, containment, and isolation of the tank atmosphere 
6. to accommodate tanks with a maximum al lowable internal-pressure differential of $+/-7.0$ in. $w . g$. relative to the atmosphere

7. to minimize installation, setup, and dismantling time

8. to use human factors, engineering principles, and a modular design approach to ensure ease of assembly, operation, and maintenance

9. to minimize the weight of a11 components as much as practical

10. to operate for a minimum of 6 months without scheduled or planned maintenance to any/all systems, subsystems, or components

11. to tolerate storage in the out-of-tank environment described in Section 3.1.

12. to provide its own utilities except for electrical

13. to operate in the environment specified in 3.1 and 3.2 , with an adequate service life to support multiple campaigns. Out-of-tank equipment shall have a reasonable service life to support the intank equipment, which has a service life determined by requirement 2.1.2.2 (1).

The LDUA Integrated System shall not

14. impose a dome load in excess of 50 tons total and 17 tons $/ \mathrm{ft}^{2}$ (OSD-T-151-00013, Operating Specifications for Single-Shel7 Waste Storage Tanks)

15. impose an axial load on a 12 in. riser in excess of $3000 \mathrm{lb}$, with a load application point which is not more than $8 \mathrm{ft}$ above the riser flange, or offset from the center line more than 6 in.

16. impose an axial load on a 4 in. riser in excess of $5001 \mathrm{~b}$, with a load application point which is not more than $8 \mathrm{ft}$ above the riser flange, or offset from the center line more than 6 in.

17. add any amount or quantity of fluids to the SSTs unless approved by appropriate tank farm organizations.

The following criteria are to ensure personnel, equipment, and environmental safety.

18. The LDUA Integrated System shall promote ALARA principles by limiting worker and environmental exposure to radiological materials, reducing the volume of secondary wastes, minimizing external contamination, and incorporating design features to ease maintenance of contaminated components.

19. The LDUA Integrated System shall be equipped with emergency stop buttons that will disable all identified hazardous energy sources (e.g., arm/deployment system and Tank Riser Interface and Confinement System [TRIC]). Emergency stop buttons shall be provided at all points of control. 
WHC-SD-TD-FRD-003, Rev. 0

20. The LDUA Integrated System control system shall provide protective interlocks to prevent equipment damage and personal injury from improper operation.

21. All hardware associated with hoisting and/or rigging for hoisting shall conform to DOE-RL-92-36, Hanford Site Hoisting and Rigging Manual.

22. Lift attach points on LDUA Integrated System equipment shall be compatible with hoisting and rigging operations.

23. LDUA Integrated System equipment shall be designed and operated to comply with WHC-CM-4-3, Industrial Safety Manual.

2.1.2.2 LDUA Integrated System In-Tank Equipment Requirements (1000). The following requirements apply to LDUA Integrated System equipment that will. operate in the in-tank environment described in Section 3.2. These requirements are in addition to the requirements in Section 2.1.2.1.

In-tank LDUA Integrated System equipment shall be designed and fabricated

1. for normal operation in a radiation field of $2000 \mathrm{rad} / \mathrm{hr}$, for equipment that operates in close proximity $(<3 \mathrm{ft}$.) to the waste surface; or in a radiation field of $1000 \mathrm{rad} / \mathrm{hr}$, for equipment that operates in the vapor space (>3 ft.) above the waste surface. Equipment must be capable of operating properly, without significant degradation in performance, until a minimum accumulated dose of $1 \times 10^{\circ}$ is attained. For equipment with an inherently $10 \mathrm{w}$ tolerance for radiation, a minimum accumulated dose of $1 \times 10^{\circ}$ may be acceptable if change-out of the equipment is sufficientiy easy. Radiation cumulative dose requirements may be met by periodic modular replacement of radiation susceptible components.

2. using materials that will withstand repeated decontamination by a varjety of methods (e.g., steam, high-pressure water, detergent and water, carbon dioxide $\left[\mathrm{CO}_{2}\right]$ pellet blasting)

3. with surface finishes that are easy to decontaminate

4. to ensure all exposed surfaces can be decontaminated

5. to maximize retrievability (i.e., in-tank equipment cannot hang up or become trapped in tank) during both normal and postfailure retrieval

6. with an outer diameter $\leq 10.5$ in. for equipment deployed through 12 in. risers or with an outer diameter $\leq 3.5$ in. for equipment deployed through 4 in. risers

7. for use in Class 1, Division 1, Group B environments as defined in NFPA 70-93, Nationa7 Electric Code.

8. to operate in the in-tank environment described in Section 3.2. 
In-tank equipment shall not

9. inadvertently or unintentionally become separated from its deployment system

10. damage the SSTs.

2.1.2.3 LDUA Integrated System Out-of-Tank Equipment Requirements $(1000)$. There are no out-of-tank requirements in addition to those in Section 2.1.2.1.

\subsubsection{LOUA Integrated System Assumptions (1000)}

\subsubsection{LDUA Integrated System General Assumptions (1000).}

1. The LDÙA Integrated System will be used on SSTs, including ferrocyanide, flammable gas, and organic watchlist tanks.

2. Electrical-power requirements for the LDUA Integrated System can be met by existing tank farm utilities.

3. The worst-case riser tilt assumption is $\mathbf{5}$ degrees.

4. The worst-case riser ground slope assumption is 10 degrees.

5. The equipment will have to be decontaminated to limits acceptable for transportation from tank farm to tank farm or to a maintenance facility on the Hanford Site. The equipment will not have to be decontaminated for release off the Hanford Site.

6. Shielding, except from riser shine, is not required in the TRIC or mast housing because in-tank equipment will be decontaminated to acceptable levels during removal.

7. The internal-tank pressure differential range of $+/-7.0$ in. w.g. relative to the atmosphere are the minimum and maximum worst cases.

8. Riser loads exceeding those listed may be acceptable; however, they will need supporting calculations and be approved by the singleshell cognizant engineer.

9. Under-current tank farm operating procedures adding fluids to SSTs requires tank farm personnel approval and may not be allowed in some tanks.

10. The risers (12 in. and 4 in.) will be characterized prior to campaign to ensure they do not exceed worst-case assumptions in terms of dimensions, orientation, and radiation levels.

11. Portable communication devices will be used for communications between the Operations Control Center and TRIC; therefore, an integrated communication system is not required.

12. The system will not be classified or have to meet the requirements of a facility. 
WHC-SD-TD-FRD-003, Rev. 0

\subsubsection{LDUA Integrated System In-Tank Equipment Assumptions (1000).}

1. The worst-case field strength $2000 \mathrm{rad}$

2. The effective inside diameter of a 12-in. riser is 10.5 in.

3. The effective inside diameter of a 4-in. riser is $3.5 \mathrm{in}$.

2.1.3.3 LDUA Integrated System Out-of-Tank Equipment Assumptions (1000). There are no out-of-tank equipment assumptions in addition to those in Section 2.1.3.1.

\subsection{ARM/DEPLOYMENT SYSTEM (2000)}

\subsubsection{Arm/Deployment System Function (2000)}

The Arm/Deployment System's primary function is to deploy, retrieve, and position the various EEs inside the tank. A secondary function of the deployment vehicle is to transport and store the arm components between campaigns.

\subsubsection{Arm/Deployment System Requirements (2000)}

The following are the general requirements for the Arm/Deployment System and are in addition to all applicable requirements in Section 2.1.2.

The Arm/Deployment System shall be designed and fabricated

1. to deploy down 12-in. existing risers

2. with a minimum usable envelope extending from $6 \mathrm{ft}$ to $49 \mathrm{ft}$ below grade (measured from the end of the mast housing to the arm's shoulder pitch centerline); the minimum usable envelope shall also include a $9-\mathrm{ft}$ hemispherical reach at the extension of the $49 \mathrm{ft}$, resulting in an overall minimum extended reach of $58 \mathrm{ft}$

3. to handle a minimum static payload of $75 \mathrm{lb}$ and a moment loading of 1000 in-1b at the EE and manipulator mating surface

4. with a positional accuracy, repeatability, resolution, and maximum speed in the working envelope as specified below:

a. With a 50 lb payload exerting a 1000 in-lb moment of:

- accuracy: \pm 0.5 in. under static conditions with the mast and arm being deployed in a plumb orientation

- repeatability: \pm 0.2 in. after settling of system motions

- resolution: 0.05 in. minimum 
b. With a 75 lo payload exerting a $1000^{\circ}$ in-16 moment of:

- accuracy: \pm 1.0 in. under static conditions with the mast and arm being deployed in a plumb orientation

- repeatability: \pm 0.2 in. after settling of system motions

- resolution: 0.05 in. minimum

c. maximum speed: 5 to $10 \mathrm{in.} / \mathrm{sec}$ for all parts of the arm

5. with arm dexterity to allow for manipulation in and around the internal-tank configuration, including obstructions such as vertical risers and other equipment

6. with all services (e.g., wiring, hoses) run internal to the arm

7. with a maximum width of $8 \mathrm{ft} 6 \mathrm{in}$. and a maximum height of $13 \mathrm{ft}$ 6 in. for the deployment vehicle and stowed system

8. with a maximum deployment vehicle turning radius of $69 \mathrm{ft}$, a maximum length of $35 \mathrm{ft}$ (including the deployment mast overhang), and the mast a minimum of $8 \mathrm{ft}$ above ground

9. so the vehicle system provides a contamination barrier for potentially contaminated arm components

10. with a remote changeout device providing a common mounting surface for EE and EE services (utilities) that includes the following features:

a. A positive latching mechanism that shall not disengage an EE during power loss or other off-normal event.

b. An EE engagement device that provides necessary seals or contamination boundaries to protect mating utility and latching connections.

c. Self-sealing fluid connectors to prevent fluid spills while mating and unmating.

11. to be horizontally deployable for maintenance

12. So that deployment will be locally controlled (at vehicle) during setup and maintenance having an incremental positioning and orientating capability with the tank riser alignment requirements

13. with a control system that maintains full control of the mast and arm (i.e., does not exhibit erratic behavior) under all operational conditions, including contact with the tank or waste.

14. to be deployable in a full SST

15. such that the mast housing provides containment of any residual contamination (radioactive or hazardous) on the mast during storage 
WHC-SD-TD-FRD-003, Rev. 0

The Arm/Deployment System shall not

16. impose loads upon the TRIC that can result in its permanent structural deformation

17. release an EE during a single-failure fault mode. 


\subsubsection{Arm/Deployment System Assumptions (2000)}

1. At least one 12-in. riser is readily available on all SSTs.

2. The maximum vehicle width and height will meet U.S. federal transportation regulations.

3. The vehicle turning radius and length requirement are based on the core drilling truck. Based on field experience with this vehicle, these dimensions should ensure the LDUA vehicle will be maneuverable within the required tank farm areas.

4. Under normal operation, the arm will not touch the waste surface. (note: end effectors attached at the wrist tool plate may come into contact with the waste surface during performance of their intended function. Contamination is not assumed to be transferred to the arm during such contact.)

\subsection{TRIC SYSTEM (3000)}

\subsubsection{TRIC System Function (3000)}

The TRIC System's function is to act as the interface between the tank riser and the LDUA Integrated System's mast deployment system. The TRIC System maintains separation between the tank atmosphere and outside environment. The TRIC System also protects personnel from exposure to contamination and provides for exchange of EES and decontamination of in-tank system components.

\subsubsection{TRIC System Requirements (3000)}

2.3.2.1 TRIC System General Requirements (3000). The following are the general requirements for the TRIC System. They are in addition to all applicable requirements in Section 2.1 .2 .

The TRIC System shall be designed and fabricated

1. with the ability to isolate enclosure from atmosphere when not connected to riser and/or deployment system

2. with local control for setup and maintenance

3. with local control for operation in the absence of the Operations Control Center

4. with video systems that, as a minimum, view mounting and dismounting of an EE from the manipulator end, the EE storage area, and the mast/arm assembly after passing through the decon system

5. with the ability to orient and adjust to align the TRIC with the riser. 
WHC-SD-TD-FRD-003, Rev. 0

2.3.2.2 TRIC System Enclosure Requirements (3100). The following requirements are specific to the TRIC System enclosure and are in addition to the requirements in Section 2.3.2.1.

The TRIC System enclosure shall be designed and fabricated

1. to allow for manipulation of equipment with a maximum weight of $200 \mathrm{lb}$

2. to limit the weight of any single component to $200 \mathrm{lb}$ or ensure components weighing in excess of $200 \mathrm{lb}$ are easily disassembled into subcomponents not weighing in excess of $200 \mathrm{lb}$

3. to interface with $12 \mathrm{in.} \mathrm{diameter} \mathrm{risers} \mathrm{between} 6 \mathrm{in.}$ and $12 \mathrm{in.}$ above the ground

4. to be compatible with the deployment vehicle and mast

5. to allow for deployment vehicle access

6. to confine contamination

7. to allow for minor, manual equipment maintenance within the enclosure

8. to house the end effector exchange system (EEES)

9. to minimize the spread of contamination within the enclosure

10. to allow for manual/assisted loading/unloading of EEs under all normal system configuration

11. to allow for removal of contaminated equipment and items

12. with accessibility to interior components requiring servicing or replacement

13. to allow manual access by operator while providing protection against contact to radiological materials or other hazards

14. to be isolated from mast housing, while either connected or not while mast is retracted

15. to be lifted and handled by a crane or forklift

16. with windows to allow operator viewing during access.

2.3.2.3 TRIC System End Effector Exchange System Requirements (3200). The following requirements are specific to the TRIC EE exchange system (EEES) and are in addition to the requirements in Section 2.3.2.1.

The TRIC System EEES shall be designed and fabricated

1. to accommodate the tilt of enclosure and arm/mast 
2. to automatically and remotely exchange EEs at the end of the arm

3. to house four EEs

4. to be maintained manually while installed in the TRIC enclosure or to be disassembled for modular removal for maintenance eternal to the TRIC.

2.3.2.4 TRIC Decon System Requirements (3300). The following requirements are specific to the TRIC decon system and are in addition to the requirements in Section 2.3.2.1.

The TRIC decon system shall be designed and fabricated

1. to isolate the TRIC from the SST when the arm is not deployed; the isolation mechanism shall provide equivalent shielding to a stee? $150-1 b, 12$ in. blind flange

2. to minimize leakage into the TRIC from the SST to prevent flammable vapors that may exist in the tank from accumulating to dangerous concentrations

3. to automatically decon in-tank LDUA Integrated System components to levels specified in Section 2.1.2.1

4. with a decon media compatible with SST farm restrictions

5. to allow for manual decontamination inside the TRIC enclosure.

2.3.2.5 TRIC Ventilation System Requirements (3400). The following requirements are specific to the TRIC ventilation system and are in addition to the requirements in Section 2.3.2.1.

The TRIC ventilation system shall be designed and fabricated

1. to meet local, state, and federal ventilation emissions requirements

2. to operate independent of existing active- or passive-tank ventilation systems

3. to filter airborne contaminants released from a tank or generated during decontamination.

\subsubsection{TRIC System Assumptions (3000)}

\subsubsection{TRIC System General Assumptions (3000).}

1. A maximum weight of 200 1b permits easy hand 7 ing of components inside the enclosure using light-duty lifting equipment.

\subsubsection{TRIC System Enclosure Assumptions (3100).}

1. The enclosure will become internally contaminated during operation. 


$$
\text { WHC-SD-TD-FRD-003, Rev. } 0
$$

\subsubsection{TRIC System EEES Assumption (3200).}

1. Four EEs are adequate to complete most campaigns.

2.3.3.4 TRIC Decon System Assumption (3300).

1. A 12 in. steel, 150-1b blind flange provides adequate shielding from radiation streaming based on present tank farm practices.

\subsubsection{TRIC Ventilation System Assumption (3400).}

1. The ventilation system will have sufficient flow rates to mitigate the concentration of flammable gas to levels well below those which could cause ignition, therefore, the ventilation and TRIC equipment design is not required to satisfy the NEC requirements for Class I Division $B$ service in explosive environments.

\subsection{OPERATIONS CONTROL CENTER (4000)}

\subsubsection{Operations Control Center Function (4000)}

The Operations Control Center houses both the equipment and personnel to remotely operate the LDUA Integrated System from outside the tank farm radiological control zone. The operations and control trailer (4100) provides a climate-controlled area for personnel and equipment. The Supervisory Control and Data Acquisition System (SCADAS) (4200) provides remote and automated control of the LOUA subsystems; integrated control of the deployment subsystem and EEs in coordinated operations; and integrated collection, display, analysis, reporting, and storage of data generated by LDUA Integrated System operations.

\subsubsection{Operations Control Center Requirements (4000)}

There are no requirements general to the operations and control trailer and the SCADAS in additions to those in Section 2.1.2.

2.4.2.1 Operations and Control Trailer Requirements (4100). The following requirements are specific to the operations and control trailers and are in addition to the requirements in Section 2.1.2.

Generically, the operations and control trailer shall provide protection from the outdoor environment in the form of shelter, heating, air conditioning, and ventilation.

The trailer shall be designed and fabricated

1. to include suitable interior lighting, as defined by the Illumination Engineering Society Lighting Handbook

2. to provide electrical power for the instrumentation and computers associated with the LDUA control system

3. with power circuits having over/under-voltage protection and isolation transformers 
4. to provide mounting space for instrumentation and control system components

5. to conform with U.S. federal transportation regulations

6. to conform with requirements in NFPA 101-91, "Life Safety Code".

2.4.2.2 SCADAS Requirements (4200). The following requirements are specific to the SCADAS and are in addition to the requirements in Section 2.1.2.

The SCADAS shall be designed and assembled to allow for the following.

1. The SCADAS shall be able to operate and control the Arm/Deployment System (2000), the TRIC (3000), and EEs (6000) individually or in automated sequences involving coordinated operation. Automated sequences shall be capable of operating in either fully automatic or single-step modes.

2. The SCADAS shall be capable of operating the LDUA Integrated System at a distance of $900 \mathrm{ft}$ from the tank equipment.

3. The SCADAS shall be able to provide graphic user interfaces for at least two simultaneous users. The graphic user interfaces shall provide windowing and shall be controlled by display-based user controls and menus that can be actuated by a pointing device. Displays shall provide equivalents to digital meter, dial meter, ribbon meter, strip chart, text, tabular, graphic displays, strip charts, and meters.

4. The SCADAS shall be able to acquire, graphically display, and store (in a database) data generated during operation. The SCADAS shall handle data from process equipment as well as EEs and manual operator input. The SCADAS shall be capable of recalling and displaying stored data. The database shall be able to tag stored data with supplemental information; (e.g., date/time, operator identity, identity of the tank and deployment riser, and position of the deployment device).

5. The SCADAS shall be able to provide local, high-capacity removable storage for data collected during operations. The SCADAS shall provide enough immediately accessible (on-line) capacity to hold all information for at least one whole tank campaign. A secondary means of storing incoming data shall be provided that can be used if the primary storage system becomes inoperable.

6. The SCADAS shall be able to provide a three-dimensional (3D) graphic display as the primary user interface for controlling the mast and arm $(2200 / 2300)$. This display shall show an animated model of the mast and arm that moves within an accurate representation of the world model (initially based on existing structural data for each tank entered by hand). The arm's animated model shall accurately show the actual positions of the mast and arm and shall follow their motions in near-real time. In addition, 
SCADAS shall allow all mast and arm motion to be previewed and checked for collisions.

7. The SCADAS shall include a display system that can display and record the views from all integrated video cameras. The system shall have
a. a minimum of two monitors
b. a minimum of two video cassette recorders, controllable by a supervisory control subsystem
c. a switching system, allowing any camera view to be displayed on any monitor or fed into either video cassette recorder
d. split-screen capability of up to four views
e. a video overlay generator that can overlay data onto video signals to annotate video recordings.

The following criteria are to ensure personnel and equipment safety.

8. A means shall be provided to ensure the SCADAS control system shall not accept commands or control inputs from more than one point of control at a time. This point of control switching mechanism shall include all points of control, both in the SCADAS and local control panels. The currently active point of control shall be displayed. Failure of the currently active point of control shall not prevent switching to another point of control. Display functions of consoles, panels, or pendants shall not be affected by point-ofcontrol switching.

9. The SCADAS shall provide alarms for failures and out-of-limit conditions.

10. The SCADAS shall provide interlocks to protect equipment from improper operation.

\subsubsection{Operations Control Center Assumptions (4000)}

\subsubsection{Operations and Control Trailer Assumptions (4100).}

1. The operations and control trailer must be located outside the tank farm perimeter fence. This location requires a maximum-cabling distance of $900 \mathrm{ft}$. The cabling distance from the operations and control trailer and at-tank equipment is estimated based on review of SST farm layout drawings.

2. Electrical-power conditioning beyond that supplied by isolation transformers and over/under-voltage protection shall be the responsibility of the instrumentation providers.

2.4.3.2 SCADAS Assumptions (4200). There are no assumptions associated with the SCADAS requirements. 


\subsection{END EFFECTOR (6000)}

\subsubsection{End Effector Functions (6000)}

End effectors developed for the LDUA Integrated System utilize sensors and effectors that perform specific surveillance, inspection, or Data Acquisition. Specific system functions are given below.

2.5.1.1 Tank Mapping Systems End Effector Function (6100). The tank mapping systems provide 3D modeling data for LDUA Integrated System operation. These data will be used to map the interior of the tank structure and waste surfaces.

2.5.1.2 Camera Systems End Effector Function (6200). The camera systems provide single-camera video, stereoscopic video, and still observation of the waste tank interior and assist in the deployment and operation of the LDUA Integrated System.

2.5.1.3 Tank Inspection Systens End Effector Function (6300). The tank inspection systems inspect welds and associated heat-affected zones, perform thickness measurements, and measure the physical dimensions of corrosion pitting on interior-tank walls and in-tank structures.

2.5.1.4 Waste Data Acquisition Systems End Effector Function (6400). The waste Data Acquisition systems measure chemica1, radiological, and physical properties of the tank waste in-situ.

\subsubsection{End Effector Systems Requirements (6000)}

2.5.2.1 Common Requirements for all End Effector Systems (6000). The following are the general requirements for EE systems and are in addition to a) 1 applicable requirements in Section 2.1.2.

1. All EE systems shall have a low-level control and data acquisition system that:

a. is responsible for basic EE system operation

b. has sufficient capability to store raw data and processed information for at least one measurement cycle when the subsystem is operated alone or supervisory-data acquisition fails in midcycle

c. can export information to the SCADAS after the measurement cycle is complete

d. is integratable with the SCADAS (4200). 
2.5.2.2 Common Requirements for Arm-Hounted End Effector Systems (6000). The following are the general requirements for arm-mounted EE Systems and are in addition to all applicabie requirements in Section 2.5.2.1.

End effectors that are mounted on the arm shall

1. have a maximum exterior-envelope diameter of $10.5 \mathrm{in}$. and be no longer than 30 in., including the EE-mounted portion of the attachment mechanism.

End effectors mounted on the arm shall not.

2. exceed a total weight of $75 \mathrm{lb}$, including the EE-mounted portion of the attachment mechanism

3. exceed a total weight of 50 1b or 75 ib respectively, to achieve the accuracy, repeatability and resolution as defined in Section 2.2 .2

4. impose a moment in excess of 1000 in. -16 at the arm interface.

2.5.2.3 Common Requirements for Nonarm-Mounted End Effector Systems (6000). The following are the general requirements for nonarm-mounted EE Systems and are in addition to all applicable requirements in Section 2.5.2.1.

End effectors deployed independent of the LDUA Integrated System shall

1. develop and utilize tank riser interface equipment that will maintain environmental integrity.

End effectors that are deployed independent of the LDUA Integrated System shall not

2. have an EE or depioyment mechanism exterior diameter in excess of 3.5 in.

3. impose an axial load on a 4 in. riser in excess of 500 ib.

2.5.2.4 Tank Mapping System End Effector Requirements (6100). The following are the requirements for tank mapping EE Systems and are in addition to all applicable requirements in Sections 2.5.2.2 and 2.5.2.3.

The tank mapping systems shall

1. generate 3D mapping data and provide graphical display of the output; data shall be made available in a format suitable for use by the LDUA Integrated System supervisory control and data acquisition system

2. provide surface measurement accuracy $\leq 0.5$ in. relative to the base of the EE

3. have a mapping density adjustable from one surface point per 1 in. by 1 in. area to one surface point per 6 in. by 6 in. area; area to be mapped shall also be adjustable 
4. provide $95 \%$ coverage of the surface area within a $30 \mathrm{ft}$. radius of the entry point of the system; exceptions are allowed when tank hardware obstructs viewing.

2.5.2.5 Camera System End Effector Requirements (6200). The following are the requirements for camera EE Systems and are in addition to all applicable requirements in Sections 2.1.2, 2.5.2.1, 2.5.2.2, and 2.5.2.3.

In general, the camera systems shall

1. carry all required 1 ighting for appropriate illumination

2. provide color imagery, zoom capabilities, and autofocusing, when practical

3. have remotely adjustable systems functions (e.g., iris control, focus, pan/tilt).

Camera systems developed for surveillance shall

4. be deployed independently of the arm if they are developed for LDUA Integrated System operations surveillance

5. provide single-camera videos and stereoscopic videos with greater than 300 lines of resolution

6. be capable of performing pan and tilt functions.

Camera systems developed for inspection shall

7. provide color stereoscopic videos with greater than 400 ines of resolution.

Camera systems developed for stereoscopic still photography shall

8. provide a way to display photographs for the stereoscopic effect

9. provide a video viewfinding capability.

Camera systems used for stereoscopic viewing shall be able to operate each camera independently of the other.

2.5.2.6 Tank Inspection System End Effector Requirements (6300). The following are the requirements for tank inspection EE Systems and are in addition to all applicable requirements in Sections 2.5.2.2 and 2.5.2.3.

Inspection systems shall

1. provide crack, corrosion pitting, and thickness measurements of the tank welds and associated heat-affected zones

2. be capable of characterizing cracks having a minimum crack (both axial and circumferential) dimension of $2 T$ long by $0.5 T$ deep with a . measurement accuracy of \pm 0.25 in. for length and \pm 0.05 in. for depth ( $T$ is the thickness of the base material being examined) 
3. be capable of characterizing corrosion pitting with a minimum diameter $0.70 \mathrm{~T}$ by $0.35 \mathrm{~T}$ deep with measurement accuracy of \pm 0.02 in.

4. be capable of measuring the wall thickness with measurement accuracy of \pm 0.0025 in.

5. provide $A, B$, and $C$ scan capabilities for systems using ultrasonics or comparable capabilities if using other NDE methods

6. have measurement accuracy of \pm 0.02 in. if performing isolated corrosion pitting measurements

7. have a horizontal and vertical position accuracy of \pm 0.25 in. relative to the base of the EE if the system requires finepositioning capabilities in addition to that provided by the LDUA Integrated System

8. have mounted video camera(s) and lighting to survey the probe and/or tank wall being inspected

9. have camera(s) with resolution of 3007 ines or greater.

2.5.2.7 Waste Data Acquisition System End Effector Requjrements (6400). The following are the requirements for waste Data Acquisition EE Systems, which are in addition to all applicable requirements in Sections 2.5.2.2 and 2.5.2.3. The requirements for the system may be met using one EE or multiple EEs. An EE may have one sensor or multiple sensors.

In general, the waste Data Acquisition system shall

1. perform in-situ waste data acquisition, including, but not limited to, temperature, compressive strength, viscosity, shear strength, tensile strength, $\mathrm{pH}$, moisture content, and speciation

2. be capable of measuring properties above and below the waste surface

a. When above the waste surface, measure the elevation above the surface using a noncontact method

3. provide a description and condition of the waste at the test location that includes
a. temperature
b. visual inspection for in-process monitoring
c. absolute time.

During compressive strength measurements, the system shall also provide

4. rate of compressive force or loading

5. elapsed time before failure 
6. compressive force at failure.

During viscosity (shear strength vs. shear rate, yield strength) measurements, the system shall also provide

7. data to support plotting of shear stress vs. shear rate, viscosity vs. shear rate, and a numerical value for yield stress point (if it exists).

During shear strength measurements, the system shall also provide

8. shear rate used.

During measurements below the waste surface, the system shall

9. be capable of operating within a 30 degree angle from the vertical direction.

10. provide protection from damage or excessive contamination during penetration preparation and sensor insertion.

\subsubsection{End Effector Assumptions (6000)}

\subsubsection{End Effector System Common Assumptions for all EEs (6000).}

1. The LDUA Integrated System will provide gross-arm position and single-1ine trajectory; scanning motion transverse to path or other fine or high-speed motions must be provided by the EE.

2.5.3.2 Tank Mapping Systems End Effector Assumptions (6100). There are no assumptions associated with the tank mapping systems EE requirements. 2.5.3.3 Camera Systems End Effector Assumptions (6200). There are no
assumptions associated with the camera systems EE requirements.

\subsubsection{Tank Inspection Systems End Effector Assumptions (6300).}

1. Specified requirements may be met by using multiple heads or EEs.

2. NDE heads using couplant may not be allowed in some SSTs because of restrictions on fluid additions.

\subsubsection{Waste Data Acquisition Systems End Effector Assumptions (6400).}

1. Specified requirements may be met by using multiple heads or EEs. 
WHC-SD-TD-FRD-003, Rev. 0

\subsection{COLD TEST FACILITY (7000)}

\subsubsection{Cold Test Facility Functions (7000)}

The cold-test facility's function is to provide a location for LDUA Integrated System integration, testing, and demonstration and system operating personnel training.

\subsubsection{Cold Test Facility Requirements (7000)}

The following are the requirements for the cold-test facility and are in addition to all applicable requirements in Section 2.1.2.

The cold-test facility shall

1. provide space and equipment necessary for testing the LDUA Integrated System

2. be representative of the actual deployment sites to allow for operator training and qualification

3. provide electrical utilities for operation in addition to other utilities specifically needed for integration, testing, demonstration, and training

4. provide simulated $4 \mathrm{in}$. and $12 \mathrm{in}$. risers

5. provide a representative tank section

6. ensure personnel (both operational and viewing) safety during setup, testing, and demonstrations

7. provide simulated waste for EE testing.

\subsubsection{Cold Test Facility Assumptions (7000)}

There are no assumptions associated with the cold Test Facility requirements. 


\subsection{ENVIRONAENTAL CONDITIONS}

This section describes the environments, both in-tank and out-of-tank, the LDUA Integrated System will experience during normal operation and must be designed to tolerate.

\subsection{OUT-OF TANK ENVIRONMENT}

The following describes the out-of-tank environment.

1. Ambient Temperature - System components shal1 be designed and constructed to function in external temperatures ranging from $-20^{\circ} \mathrm{F}$ to $+120^{\circ} \mathrm{F}$ and shall be designed to tolerate additional heat loads resulting from operation in direct sunlight.

2. Storage Temperature - System components shall be designed to be stored in outdoor containers with an internal temperature range of $-20^{\circ} \mathrm{F}$ to $+150^{\circ} \mathrm{F}$.

3. Relative Humidity - System components shall be designed and constructed to function in external-humidity environments ranging from $4 \%$ to $100 \%$.

4. Wind Speed - System components shall be designed and constructed to operate in external wind up to $40 \mathrm{mph}$ and be able to withstand winds up to $80 \mathrm{mph}$.

5. Moisture - System components shall be designed and constructed to function in external-rain environments with rainfall up to 2 in./h.

6. Snow - System components must be able to function in periodic-snow environments with snowfall accumulations of $2 \mathrm{ft}$.

7. Dust - System components shall be designed and constructed to function in an environment with periodically-severe dust storms.

8. Topography - All tank farm equipment must be able to operate (or be leveled to operate) on terraces with slopes up to $10 \%$ and berms or curbs up to 6 -in. high.

9. Obstacles - Maneuverability within the tank farm area must consider access through gates, above-ground ducts, and other above-ground equipment.

\subsection{IN-TANK ENVIRONAENT}

The following describes the in-tank environment.

1. Temperature - In-tank temperatures range from $+50^{\circ} \mathrm{F}$ to $+150^{\circ} \mathrm{F}$.

2. Humidity - The relative humidity ranges from $10 \%$ to $100 \%$. 


\section{WHC-SD-TD-FRD-003, Rev. 0}

3. Dust - Some tanks may have airborne abrasive dust.

4. Chemical - The chemical environment can vary from concentrated nitric acid fumes to waste material with a $\mathrm{pH}$ of 14 .

5. Explosive gasses - explosive gases may be present in some tanks.

6. Forms of Waste:
a. supernate
b. sludge (soft)
c. hard sludge (peanut butter)
d. hard saltcake (concrete) 
WHC-SD-TD-FRD-003, Rev. 0

\subsection{REFERENCES}

DOE-RL-92-36, Hanford Site Hoisting and Rigging Manual, U.S. Department of Energy, Richland Operations Office, Richland, Washington, 1993.

NFPA 70-93, National Electric Code, National Fire Protection Association, Batterymarch Park, Massachusetts, 1993.

NFPA 101-91, Life Safety Code, National Fire Protection Association, Batterymarch Park, Massachusetts, 1991.

0SD-T-151-00013, Operating Specifications for Single-Shell Waste Storage Tanks," West inghouse Hanford Company, Richland, Washington, S. D. Godfrey, 1992.

WHC-CM-4-3, Industrial Safety Manual, Westinghouse Hanford Company, Industrial Safety and Fire Protection, Richland, Washington, 1987. 


$$
\text { WHC-SD-TD-FRD-003, Rev. } 0
$$

\subsection{REQUIREMENTS DOCUMENTS}

NFPA 70-93, National Electric Code, National Fire Protection Association, Batterymarch Park, Massachusetts, 1993.

NFPA 101-91, Life Safety Code, National Fire Protection Association, Batterymarch Park, Massachusetts, 1991.

OSD-T-151-00007, Operating Specifications for 241-AN, AP, AW, AY, AZ, \& SY Tank Farms, Westinghouse Hanford Company, Richland, Washington, S. D. Godfrey, 1992.

OSD-T-151-00030, Operating Specifications for Watch List Tanks, Westinghouse Hanford Company, Richland, Washington, S. D. Godfrey, 1992.

WHC-CM-4-9, Radiological Design Manual, Westinghouse Hanford Company, Radiological Assessments, Packaging and Shipping, Richland, Washington, 1988.

WHC-CM-4-11, ALARA Program Manual, Westinghouse Hanford Company, Radiological Engineering, Richland, Washington, 1988.

WHC-CM-7-5, Environmental Compliance Manual, Westinghouse Hanford Company, Regulator Compliance, Richland, Washington, 1988.

WHC-SD-WM-WP-231, LDUA Safety Program Plan, Westinghouse Hanford Company, Richland, Washington, R. L. Guthrie, 1993. 


\subsection{BIBLIOGRAPHY}

SD-WM-SAR-022, Hazard Identification and Evaluation for Nonstabilized SingleShell Tanks, Westinghouse Hanford Company, Richland Washington, D. A. Smith, 1986.

WHC-EP-0539, Regulatory Analysis of the Underground Storage Tank-Integrated Demonstration Program, Westinghouse Hanford Company, Richland, Washington, E. H. Smith, Rev. 1, 1992.

WHC-SD-RE-TI-053, Riser Configuration Document for Single-Shell Waste Tanks, Westinghouse Hanford Company, Richland, Washington, A. T. Alstad, Rev. 9, 1993.

WHC-SD-WM-ER-204, Letter Report-Single Shell Tank Riser Configuration, KEH Work Order ER3714, Westinghouse Hanford Company, Richland, Washington, T. D. Boucher, 1993.

WHC-SD-WM-PC-002, Tank Farms Essential Support Drawing P7an, Westinghouse Hanford Company, Richland, Washington, B. E. Salazar, Rev. 5, 1993.

WHC-SD-WM-SEL-027, Single Shell Waste Tanks Interim Safety Equipment List, Westinghouse Hanford Company, Richland, Washington, R. J. Kidder, Rev 1,
1994.

WHC-SD-WM-SEL-032, Rotary Mode Core Sampling Safety Equipment List, Westinghouse Hanford Company, Richland, Washington, J. E. Corbett, Rev. 1, 1994.

WIN-107-4.2 Draft, Safety Analysis for Visual Inspection of the HLLW Tanks, Idaho National Engineering Laboratory, 1993.

WM-RTI-SO-12, RTI Robotic System Operability Test Procedure, Idaho National Engineering Laboratory, 1993. 
WHC-SD-TD-FRD-003, Rev. 0

\title{
GLOSSARY
}

\author{
ABBREVIATIONS, ACRONYMS, AND INITIALISMS \\ 30 \\ three dimensional \\ ALARA as low as reasonably achievable \\ DOE U.S. Department of Energy \\ DOE-RL U.S. Department of Energy-Richland Operations \\ EE \\ end effector \\ end effector exchange system \\ EEES \\ F\&R \\ LDUA \\ Functions, Requirements \& Assumptions \\ Light-Duty Utility Arm \\ SCADAS \\ SST \\ TRIC \\ UST-ID \\ WHC \\ supervisory control and data acquisition system \\ single-shell tank \\ Tank Riser Interface Confinement System \\ Underground Storage Tank - Integrated Demonstration \\ Westinghouse Hanford Company
}

\section{DEFINITIONS OF TERHS}

Assumption. An assumption is a basis for a requirement that is taken to be true without necessarily having proof or demonstration. Changes in assumptions may have significant impacts on related requirements.

Cold Test Facility. A facility used to test and demonstrate the Integrated System that will not utilize any radioactive or hazardous material.

Function. A function is a description of the task a system, subsystem, or component must perform. It is not a description of the device in any manner, but may establish some of the parameters within which the device must perform.

Requirement. A requirement is a mandatory factor that must be applied or incorporated into the design of the device performing the specified function. It is not a preference and uses the word "shall."

System Numbers.

1000. LDUA Integrated System

2000. Arm/Deployment System

3000. TRIC System

4000. Operations Control Center

6000. End Effectors

7000. Cold Test Facility 


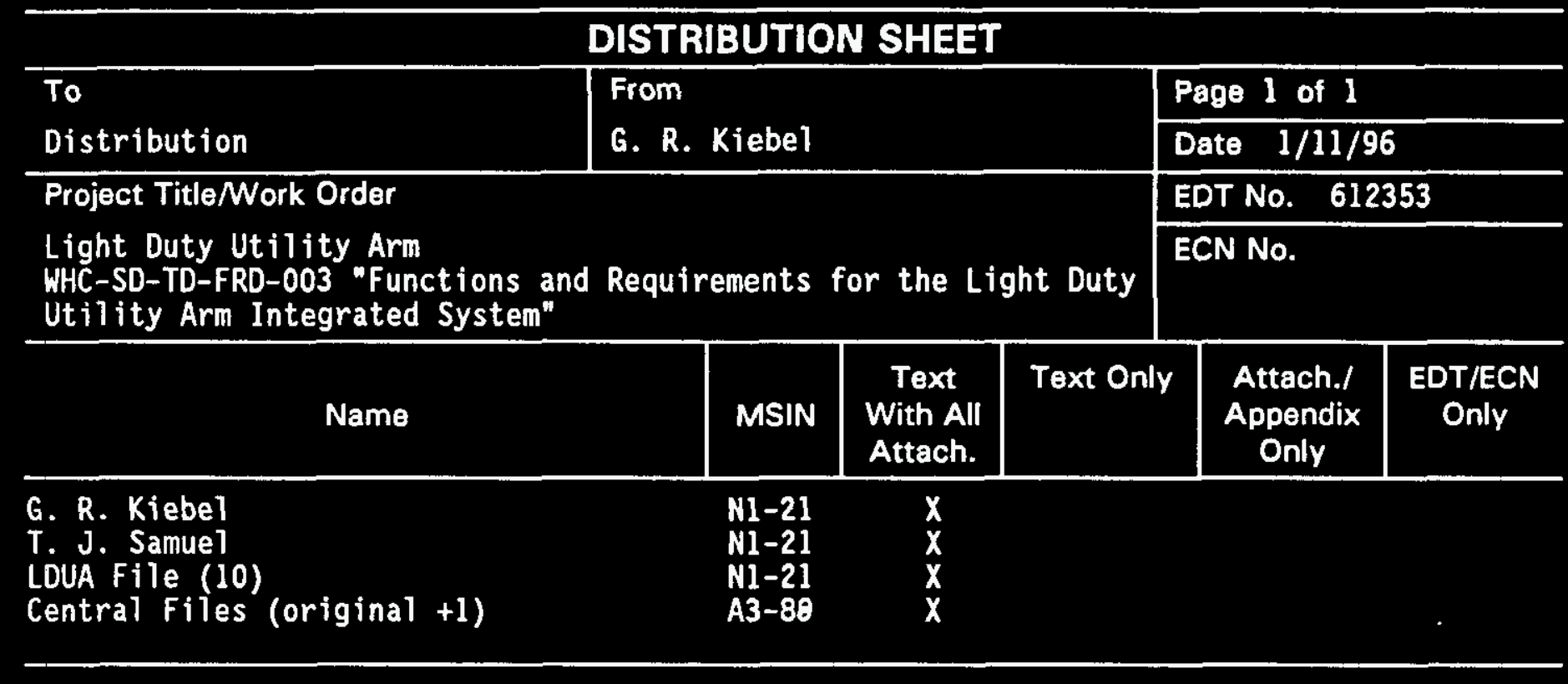

